\title{
The natural history and functional consequences of dysphagia after hemispheric stroke
}

\author{
D H BARER
}

\author{
From the Department of Medicine, University Hospital, Nottingham, UK
}

SUMMARY Data from 357 conscious stroke patients taking part in an acute intervention trial and $\frac{\bar{C}}{5}$ assessed within 48 hours of the onset of symptoms, were used to investigate the prevalence and $\frac{\bar{m}}{\bar{m}}$ natural history of swallowing problems. Nearly $30 \%$ of patients with single-hemisphere strokes were $\stackrel{\otimes}{\&}$ initially found to have difficulty swallowing a mouthful of water, but in most of those who survived, 放 the deficit had resolved by the end of the first week. Strong correlations were found between dysphagia and speech impairment (comprehension and expression) and with facial weakness, but there was no association with the side of the stroke. After controlling for other markers of overall $\vec{\omega}$ stroke severity such as conscious level, urinary continence, white blood cell count and strength in the $\frac{\text { S }}{3}$ affected limbs, swallowing impairment still showed a significant inverse correlation with functional ability at 1 and 6 months. These results indicate that, even if dysphagia itself is not responsible for or much excess mortality in acute stroke, it might still lead to complications which hamper functional in recovery.

Dysphagia is a common and serious problem after strokes involving both cerebral hemispheres or the brainstem. Because of the bilateral upper motor neuron innervation of most of the lower cranial nerves involved in swallowing, many textbooks state that the mechanism of deglutition is not significantly affected by damage to a single cerebral hemisphere. Recently, however, it has been pointed out that unilateral hemisphere strokes do affect lower cranial nerve function in general ${ }^{1}$ and swallowing in particular. ${ }^{2-5}$

Clearly, swallowing problems could have serious consequences, with dehydration leading to haemoconcentration, impaired cerebral perfusion and renal failure, and aspiration leading to pneumonia. Data obtained from observations on 357 conscious stroke victims taking part in a trial of beta blockers in acute stroke (the "BEST" Study ${ }^{67}$ ) were used to investigate this possibility and to give more detailed information on the natural history of dysphagia after stroke. The results are presented here and the relationships between swallowing problems and other neurological deficits are explored.

\section{Patients and methods}

Patients taking part in the BEST Study were selected from a register of all stroke admissions to the acute wards of

Address for reprint requests: Dr D H Barer, Department of Health Care of the Elderly, University Hospital, Nottingham NG7 2UH, UK

Received 8 July 1988.

Accepted 9 October 1988
Nottingham City and University Hospitals, according to th following criteria:

1. Onset of hemisphere stroke within 48 hours,

2. Conscious and able to take oral medication,

3. No major pre-stroke physical or mental disability,

4. No evidence of acute myocardial infarction or oth possible cause of a sudden serious fall in cerebral perfusior

5. No beta blocker contra-indications (such as bradycar dia, heart block, hypotension, heart failure, asthma).

Patients fulfilling these criteria were assessed according to a fixed protocol on admission, on day 8 , and at 1 and 6 months by one of three investigators. Three hundred and two patients were entered into the BEST Trial and a further 60 who would have been eligible had they not been taking beta blockers at the time of the stroke were followed up in the same way. Ninety-five percent of these 362 patients had all their assessments carried out by the author, and in all those who had been entered into the study by other investigators the signs were confirmed within 24 hours: thus the effect of observer variation was minimised.

\section{Assessment of swallowing}

The patient was asked to swallow a $10 \mathrm{ml}$ mouthful of water from a cup or feeding beaker. If this could be done with no more than minor difficulty, swallowing was rated as normal (grade 1), but if there was a marked delay or coughing on more than one occasion, swallowing was rated "impaired" (grade 2). If swallowing was so severely affected that fluid had to be given by nasogastric tube or intravenous drip, it was rated "grade 3", but patients with this degree of dysphagia on admission were nearly all excluded from the BEST Study. Swallowing was not assessed in unconscious patients, and no attempt was made to define the precise pattern of neurological impairment by testing such features as palatal 
sensation or vocal cord apposition.

Details of the neurological and functional assessments have been given elsewhere ${ }^{8}$ but definitions of the clinical signs used in the present analysis are given in the Appendix. Activities of daily living (ADL) were assessed on a 10-point scale specifically designed and validated for stroke patients. 9 The activities are in order of difficulty so that, for instance, nearly all patients with a score of 4 will be able to feed, wash and transfer from bed to chair, but not to walk or dress independently.

\section{Results}

Frequency of swallowing problems among BEST study patients

Of the 362 patients in the BEST Study, 357 were thought on clinical grounds to have involvement of a single cerebral hemisphere. In 85 of these patients, the clinical diagnosis was verified by brainscan or post mortem examination and in all but two $(2 \%)$ of these cases the lesion was found to be in the hemisphere predicted clinically. One patient was found to have damage to both hemispheres and the other to have a brainstem lesion.

Table 1 shows the frequency of swallowing impairment (grades 2 and 3 combined) in various subgroups of these 357 patients at different times after the stroke. Initially nearly one third of patients with single-hemisphere strokes had significant difficulty with swallowing. As expected, dysphagia was much more common amongst those who were drowsy on admission, but there were also highly significant associations with conjugate gaze paresis and sensory inattention. Older patients were more likely to have swallowing problems initially but the age difference was much smaller by the end of the first week, possibly because of the high mortality among elderly patients with dysphagia.

There was no significant difference in the frequency of swallowing problems with left and right sided lesions. It can also be seen that these problems subsided very quickly in most patients if they survived, so that by 1 month, only $2 \%$ of those survivors with unilateral damage were still having difficulty with swallowing.

\section{Speed of resolution of dysphagia in various groups}

The likelihood of improvement in dysphagia over the first few weeks is compared between patient groups in table 2 . Here, only patients who survived and who had impaired swallowing at the beginning of the time interval in question are considered. Over half of those with problems on day 1 had improved by at least one grade by the end of the first week, resolution being more rapid in the milder group without initial impairment of consciousness, gaze deviation or sensory inattention. Total patient numbers are much smaller in this table so that small age-related and other differences cannot be excluded with confidence.

tble 1 Frequency of swallowing impairment in various subgroups (unilateral hemisphere lesions only)

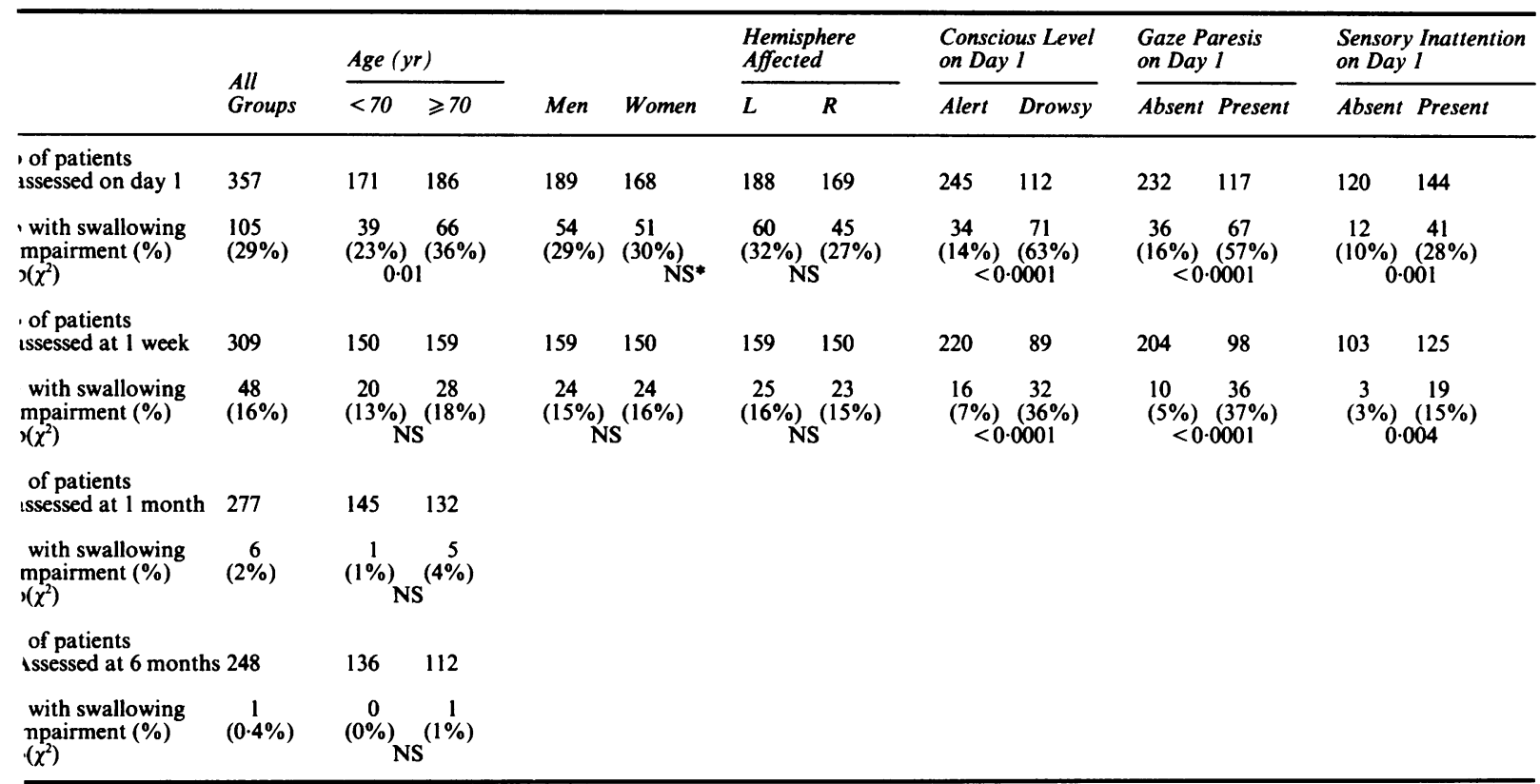


Table 2 Proportion of surviving patients with impaired swallowing showing improvement between assessments

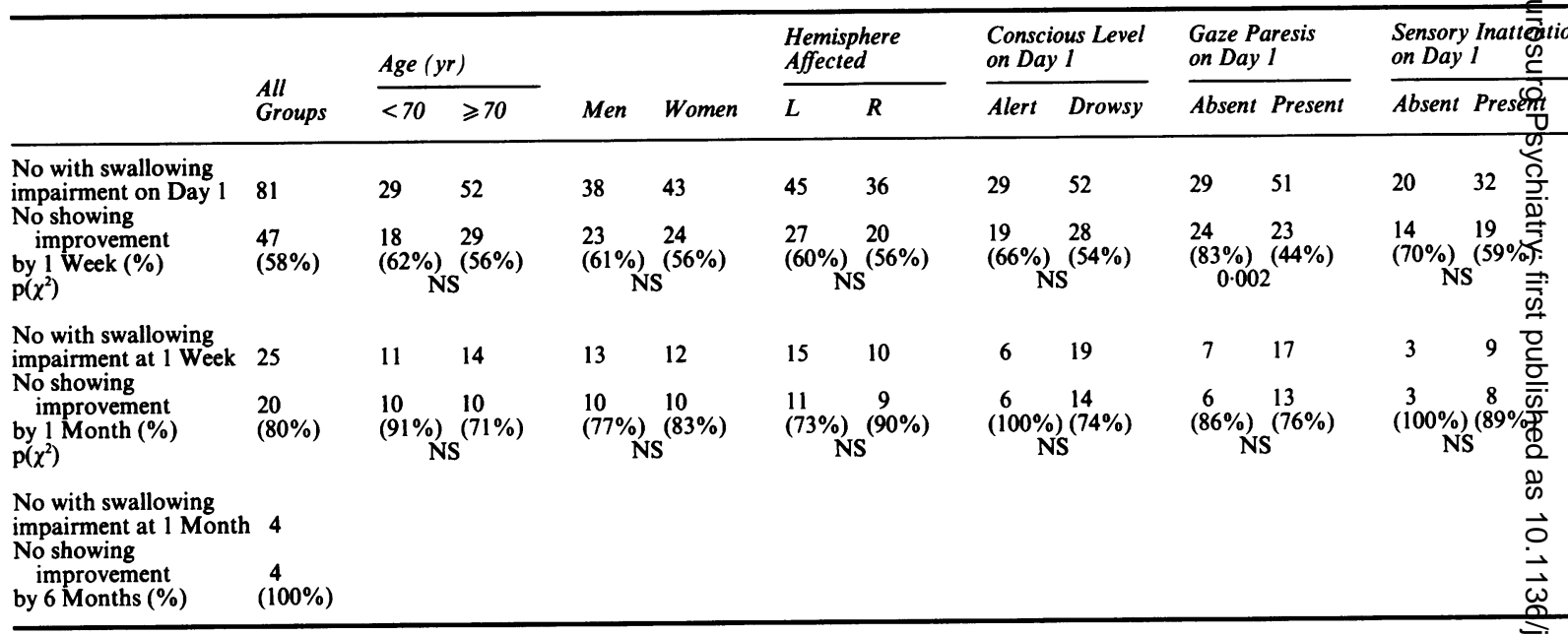

Relationship of dysphagia to other neurological signs Table 1 showed that swallowing impairment was closely associated with conscious level, gaze paresis and sensory inattention. These and other neurological signs are all markers of stroke severity, and thus strongly interrelated. Two good indicators of overall stroke severity, shown to be largely independent of each other in the BEST Study, are conscious level and white blood cell count. ${ }^{10}$ In table 3 , the relationships between swallowing and other neurological impairments are examined before and after adjusting for these two factors by means of multiple linear regression analysis. The direct correlations (Pearson) in the first row indicate strong associations $(p<0.001)$ between swallowing impairment and all the other neurological signs considered. Rows 2 to 5 show partial correlation coefficients which indicate the strength of these associations after allowing for the effects of the "control" variables.
Controlling for side of stroke improves the correlations with "speech intelligibility" and "response to $\mathrm{N}$ commands" (that is, expressive and receptive lan - iv guage) to some extent. When differences in white blood count between individuals are allowed for, thit strength of the correlations diminishes slightly, bug when the effect of conscious level is taken out there is $\vec{a} \vec{T}$ marked drop in all the partial correlation coefficients Controlling for all three variables simultaneous $B$ reveals that the apparent relationship between swat lowing and sensory inattention is mainly dependent conscious level, but that the other associations are stifi significant.

\section{Prognostic significance of dysphagia}

From table 4 it can be seen that swallowing impairment was associated with poor outcome whatever the initial level of consciousness.

Patients whose swallowing is impaired, but not $\overrightarrow{\vec{\rho}}$

Table 3 Partial correlation coefficients relating swallowing impairment to other neurological variables on day 1

\begin{tabular}{|c|c|c|c|c|c|c|c|c|c|}
\hline \multirow[b]{3}{*}{ Control variables } & \multicolumn{9}{|c|}{ Variables correlated with swallowing } \\
\hline & \multirow[b]{2}{*}{$\begin{array}{l}\text { Speech } \\
\text { intelligibility } \\
(1-4)^{*}\end{array}$} & \multirow[b]{2}{*}{$\begin{array}{l}\text { Urinary } \\
\text { continence } \\
(1-3)\end{array}$} & \multirow[b]{2}{*}{$\begin{array}{l}\text { Conjugate } \\
\text { gaze } \\
(1-3)\end{array}$} & \multirow[b]{2}{*}{$\begin{array}{l}\text { Response to } \\
\text { commands } \\
(1-3)\end{array}$} & \multicolumn{3}{|c|}{ Power on affected side } & \multirow[b]{2}{*}{$\begin{array}{l}\text { Visual } \\
\text { fields } \\
(1-3)\end{array}$} & \multirow[b]{2}{*}{$\begin{array}{l}\text { Sensory } \\
\text { inattention } \\
(1-3)\end{array}$} \\
\hline & & & & & $\underset{(1-5)}{\operatorname{Leg}}$ & $\underset{(1-5)}{A r m}$ & $\begin{array}{l}\text { Face } \\
(1-2)\end{array}$ & & \\
\hline $\begin{array}{l}\text { Partial correlation coefficient } \\
\text { after adjusting for: }\end{array}$ & 0.43 & 0.43 & 0.37 & $0 \cdot 37$ & 0.35 & $0 \cdot 32$ & $0 \cdot 28$ & $0 \cdot 32$ & 0.25 \\
\hline $\begin{array}{l}\text { Side of stroke (S) } \\
\text { White blood cell count (W) } \\
\text { Conscious level (C) } \\
\text { S, W and C }\end{array}$ & $\begin{array}{l}0.46 \\
0.40 \\
0.29 \\
0.30\end{array}$ & $\begin{array}{l}0.43 \\
0.39 \\
0.24 \\
0.23\end{array}$ & $\begin{array}{l}0.38 \\
0.36 \\
0.19 \\
0.19\end{array}$ & $\begin{array}{l}0.41 \\
0.33 \\
0.25 \\
0.27\end{array}$ & $\begin{array}{l}0 \cdot 35 \\
0 \cdot 31 \\
0 \cdot 16 \\
0 \cdot 14\end{array}$ & $\begin{array}{l}0.32 \\
0.28 \\
0.13 \\
0.12\end{array}$ & $\begin{array}{l}0.28 \\
0.25 \\
0.17 \\
0.16\end{array}$ & $\begin{array}{l}0 \cdot 32 \\
0 \cdot 28 \\
0 \cdot 14 \\
0 \cdot 12\end{array}$ & $\begin{array}{l}0 \cdot 25 \\
0 \cdot 20 \\
{[0.01]} \\
{[0.01]}\end{array}$ \\
\hline \multicolumn{10}{|c|}{$\begin{array}{l}\text { *(1-4)= range of possible values on rating scale (see Appendix) } \\
\text { Approximate } p \text { values for correlations: Coefficient } \geqslant 0.18 p p<0.001 \\
\text { Coefficient } 0.13-0.170 .001<p<0.01 \\
\text { Coefficient } 0.09-0.120 .01<p<0.05 \quad p>0.1 \text { coefficient in brackets [ ] }\end{array}$} \\
\hline
\end{tabular}


Table 4 Outcome at 1 week, 1 month and 6 months according to initial conscious level and swallowing ability

\begin{tabular}{|c|c|c|c|c|c|c|c|c|c|c|}
\hline \multirow[b]{2}{*}{$\begin{array}{l}\text { Conscious Level } \\
\text { on Day } 1\end{array}$} & \multirow[b]{2}{*}{$\begin{array}{l}\text { Swallowing } \\
\text { on Day I }\end{array}$} & \multicolumn{3}{|c|}{ Status at 1 Week } & \multicolumn{3}{|c|}{ Status at 1 Month } & \multicolumn{3}{|c|}{ Status at 6 Months } \\
\hline & & $\begin{array}{l}\text { At Home } \\
\text { No }(\%)\end{array}$ & $\begin{array}{l}\text { Hospital } \\
\text { No }\end{array}$ & $\begin{array}{l}\text { Dead } \\
\text { No }(\%)\end{array}$ & $\begin{array}{l}\text { At Home } \\
\text { No }(\%)\end{array}$ & $\begin{array}{l}\text { Hospital } \\
\text { No }\end{array}$ & $\begin{array}{l}\text { Dead } \\
\text { No }(\%)\end{array}$ & $\begin{array}{l}\text { At Home } \\
\text { No }(\%)\end{array}$ & $\begin{array}{l}\text { Hospital } \\
\text { No }\end{array}$ & $\begin{array}{l}\text { Dead } \\
\text { No }(\%)\end{array}$ \\
\hline $\begin{array}{l}\text { Alert } \\
\mathrm{p}\left(\chi^{2}\right)^{*}\end{array}$ & $\begin{array}{l}\text { Normal } \\
\text { Impaired }\end{array}$ & $\begin{array}{l}35(17) \\
0(0)\end{array}$ & $\begin{array}{c}171 \\
30 \\
0.002\end{array}$ & $\begin{array}{l}5(2) \\
4(12)\end{array}$ & $\begin{array}{l}98(46) \\
11(32)\end{array}$ & $\begin{array}{l}98 \\
12 \\
0 \cdot 0001\end{array}$ & $\begin{array}{l}15(7) \\
11(32)\end{array}$ & $\begin{array}{r}160(76) \\
16(47)\end{array}$ & $\begin{array}{l}21 \\
3 \\
0.0001\end{array}$ & $\begin{array}{l}29(14) \\
15(44)\end{array}$ \\
\hline $\begin{array}{l}\text { Drowsy } \\
\mathrm{p}\left(\chi^{2}\right)\end{array}$ & $\begin{array}{l}\text { Normal } \\
\text { Impaired }\end{array}$ & $\begin{array}{ll}1 & (2) \\
0 & (0)\end{array}$ & $\begin{array}{c}36 \\
52 \\
0.05\end{array}$ & $\begin{array}{r}4(10) \\
19(27)\end{array}$ & $\begin{array}{ll}3 & (7) \\
0 & (0)\end{array}$ & $\begin{array}{l}29 \\
33 \\
0.001\end{array}$ & $\begin{array}{r}9(22) \\
38(54)\end{array}$ & $\begin{array}{l}26(65) \\
16(23)\end{array}$ & $\begin{array}{l}5 \\
10 \\
<0 \\
<\end{array}$ & $\begin{array}{r}9(23) \\
45(63)\end{array}$ \\
\hline
\end{tabular}

${ }^{*} \chi^{2}$ with 2 degrees of freedom

badly enough to need intravenous or nasogastric fluid, might become mildly dehydrated, and table 5 shows mean values of haematological variables in those with and without dysphagia. The only haematological factor associated with swallowing impairment on day 1 was a raised white cell count, which was probably just a marker of overall stroke severity. Blood urea and haematocrit levels were no higher initially and did not raise significantly faster during the first week in those with than in those without dysphagia. Patients whose swallowing difficulties persisted into the second week tended to have higher white cell counts and urea levels but again, their haematocrit levels were not significantly higher, suggesting that dehydration was a relatively minor factor.

Comparison of the causes of death in BEST Study patients did not reveal any major difference in the pattern of deaths in patients with and without dysphagia,${ }^{6}$ apart from a slight excess of early deaths from primary brain damage, as would be expected in a group with more extensive strokes.

Can the effect of stroke severity be allowed for in order to assess the independent effect of dysphagia on functional recovery in a more objective way? An attempt to do this is shown in table 6 which again makes use of partial correlation coefficients obtained from multiple linear regression analysis. Each variable shown is correlated with the 10-point ADL scores at 6 months (dead patients being given a score of 0 ) both before and after adjusting for various indicators of stroke severity.

As in table 3 the direct correlations are very strong, but the values drop sharply when the effect of conscious level is allowed for. Controlling for two other important indicators of stroke severity, urinary continence and white blood cell count, results in a further reduction of the strength of associaiton, but further adjustment for age makes little difference. Even at this stage, however, some of the residual correlations might depend on the interrelations between the neurological variables referred to above. When allowance is made for strength in the affected leg, only swallowing, visual fields and sensory inattention retain a significant independent association with outcome.

\section{Discussion}

Even if most of the muscles involved in swallowing receive efferent fibres from both cerebral hemispheres, it is not surprising that damage to one side can disrupt this delicate mechanism, if only temporarily. The exact site of cortical representation for swallowing is not known, but some indications can be discerned from the pattern of relationships between dysphagia and other neurological signs. In table 3 we saw that swallowing was more closely related to speech and function in the facial muscles than to motor function in the limbs. Disruption of corticobulbar pathways is

Table 5 Mean values of, and mean changes in haematological variables according to grade of swallowing

\begin{tabular}{|c|c|c|c|c|c|c|c|c|c|}
\hline \multirow[b]{2}{*}{$\begin{array}{ll}\text { Grade of swallowing* } \\
\text { Day } 1 & 1 . \\
& 2 . \\
\text { p(F-test) } & 3 .\end{array}$} & \multirow[b]{2}{*}{$\begin{array}{r}\text { n } \\
250 \\
99 \\
8\end{array}$} & \multicolumn{2}{|c|}{ Packed cell volume (\%) } & \multicolumn{4}{|c|}{ White cell count $\left(\times 10^{9} / l\right)$ Blood urea $(\mathrm{mMol} / \mathrm{l})$} & \multicolumn{2}{|c|}{ Blood glucose (mMol/l) } \\
\hline & & $\begin{array}{l}\text { Day } 1 \\
44 \cdot 6 \\
44 \cdot 3 \\
46 \cdot 8 \\
\text { NS }\end{array}$ & $\begin{array}{l}\text { Day } 8-\text { Day } 1 \\
\quad-1.0 \\
-0.6 \\
-0.7 \\
\text { NS }\end{array}$ & $\begin{array}{l}\text { Day } 1 \\
9 \cdot 9 \\
11 \cdot 1 \\
13 \cdot 5 \\
0 \cdot 0002\end{array}$ & $\begin{array}{l}\text { Day } 8 \text { - Day } 1 \\
\quad-0.7 \\
-0.1 \\
+0.3\end{array}$ & $\begin{array}{l}\text { Day } 1 \\
6 \cdot 5 \\
7 \cdot 2 \\
6 \cdot 8 \\
\text { NS }\end{array}$ & $\begin{array}{l}\text { Day } 8 \text {-Day } 1 \\
\quad+2 \cdot 1 \\
\quad+3 \cdot 5 \\
\quad+3 \cdot 2 \\
\text { NS }\end{array}$ & $\begin{array}{l}\text { Day } 1 \\
7 \cdot 3 \\
7 \cdot 7 \\
8 \cdot 4 \\
\text { NS }\end{array}$ & $\begin{array}{l}\text { Day } 8-\text { Day } 1 \\
\quad+0.4 \\
\quad+0.4 \\
+1.0 \\
\mathrm{NS}\end{array}$ \\
\hline $\begin{array}{l}\text { Day } 8 \\
\text { p(F-test) }\end{array}$ & $\begin{array}{r}\text { n } \\
234 \\
29 \\
13\end{array}$ & & $\begin{array}{l}\text { Day } 8 \\
43 \cdot 3 \\
44 \cdot 4 \\
45 \cdot 3 \\
\text { NS }\end{array}$ & & $\begin{array}{c}\text { Day } 8 \\
9.4 \\
11 \cdot 1 \\
11 \cdot 9 \\
0.001\end{array}$ & & $\begin{array}{l}\text { Day } 8 \\
8 \cdot 3 \\
11 \cdot 9 \\
12 \cdot 1 \\
0 \cdot 0001\end{array}$ & & $\begin{array}{c}\text { Day } 8 \\
7 \cdot 5 \\
8 \cdot 8 \\
7 \cdot 6 \\
\text { NS }\end{array}$ \\
\hline
\end{tabular}

*1 = Normal, 2 = Mild/moderate impairment, 3 = Severe impairment (needing nasogastric or intravenous fluids) 
Table 6 Partial correlation coefficients relating swallowing impairment and other neurological variables on day 1 to functional outcome at 6 months, before and after adjustment for overall stroke severity (All correlations shown are negative)

\begin{tabular}{|c|c|c|c|c|c|c|c|c|}
\hline \multirow[b]{3}{*}{ Control variables } & \multicolumn{8}{|c|}{ Variables correlated with ADL score at 6 months } \\
\hline & \multirow[b]{2}{*}{$\begin{array}{l}\text { Swallowing } \\
(1-3)^{*}\end{array}$} & \multirow{2}{*}{$\begin{array}{l}\text { Speech } \\
\text { intelligibility } \\
(1-4)\end{array}$} & \multirow[b]{2}{*}{$\begin{array}{l}\text { Conjugate } \\
\text { gaze } \\
(1-3)\end{array}$} & \multicolumn{3}{|c|}{ Power on affected side } & \multirow[b]{2}{*}{$\begin{array}{l}\text { Visual } \\
\text { fields } \\
(1-3)\end{array}$} & \multirow[b]{2}{*}{$\begin{array}{l}\text { Sensory } \\
\text { inattention } \\
(1-3)\end{array}$} \\
\hline & & & & $\operatorname{Leg}_{(1-5)}$ & $\underset{(1-5)}{\operatorname{Arm}}$ & $\begin{array}{l}\text { Face } \\
(1-2)\end{array}$ & & \\
\hline \multirow{4}{*}{$\begin{array}{l}\text { Partial correlation coefficients } \\
\text { after adjusting for: } \\
\text { Conscious level (C) } \\
\text { C, Bladder control (B), } \\
\text { white cell count (W) }\end{array}$} & 0.42 & 0.36 & 0.34 & 0.45 & $0 \cdot 38$ & 0.22 & 0.43 & $0 \cdot 39$ \\
\hline & & & & & & & & \\
\hline & $0 \cdot 29$ & 0.24 & $0 \cdot 19$ & 0.32 & $0 \cdot 25$ & $0 \cdot 13$ & $0 \cdot 31$ & 0.24 \\
\hline & $0 \cdot 21$ & 0.09 & $0 \cdot 12$ & $0 \cdot 18$ & $0 \cdot 13$ & 0.08 & $0 \cdot 22$ & $0 \cdot 16$ \\
\hline \multirow{2}{*}{$\begin{array}{l}\text { C, B, W, Age } \\
\text { C, B, W, Age, Strength in } \\
\text { affected leg }\end{array}$} & $0 \cdot 20$ & $0 \cdot 10$ & 0.09 & $0 \cdot 17$ & $0 \cdot 13$ & 0.09 & 0.23 & 0.18 \\
\hline & 0.19 & {$[0.08]$} & {$[0.07]$} & - & {$[0.02]$} & {$[0 \cdot 06]$} & 0.23 & 0.19 \\
\hline
\end{tabular}

Approximate $\mathrm{p}$ values for correlations: Coefficient $>0.18 \mathrm{p}<0.001$

Coefficient $0.13-0.170 .001<p<0.01$

Coefficient $0.09-0.120 .01<\mathrm{p}<0.05$

Coefficient 0.07-0.08 0.05 $<\mathrm{p}<0.1 \mathrm{p}>0.05$ [coefficient in brackets] [].

likely to affect articulation and movements of the lower half of the face as well as swallowing, but the association with comprehension is harder to explain, as are the slightly weaker associations with urinary continence and conjugate gaze paresis, for which the neuroanatomical basis is less obvious. The symmetry of these observations is striking in that relationships are equally strong for left and right sided strokes.

Investigation of dysphagia in stroke patients was not the primary aim of the BEST Study, and the assessment of swallowing was somewhat crude. Furthermore, patients unable to swallow tablets on admission were excluded from the study. Nevertheless the detection at a bedside neurological examination of a group of conscious stroke victims with mild to moderate dysphagia raises important questions as to how they should be managed. When associated with other adverse signs such as drowsiness or incontinence, dysphagia indicates a grave prognosis, but in patients with hemispheric strokes who survive a week or more swallowing usually improves rapidly. Should all such patients be given intravenous or nasogastric fluid and perhaps even prophylactic antibiotics?

The theoretical aim is to prevent dehydration, but the results shown in table 5 provide little evidence that initial dysphagia was associated with significant haemoconcentration and uraemia. Gordon $e t a l,{ }^{5}$ on the other hand, made repeated blood measurements on 64 patients with acute stroke and found that nine of the 33 with impaired swallowing had a PCV of over $48 \%$ at some time during the first week, compared with four of 31 patients without dysphagia. Nevertheless, despite the fact that even at this level of haematocrit, blood viscosity is starting to increase, recent studies have shown that the excess morbidity and mortality attributable to haemoconcentration of this degree is very small and not preventable by haemodilution. ${ }^{11} 12$

Morbidity and mortality associated with aspiration $N$ is much harder to estimate. No standardised assesso in ment of chest infection has been validated for use this situation and pneumonia is a common termin ब1 event in patients with severe strokes, in whom survival would have been at the expense of crippling disabilit 7 On the other hand, the present results indicate that $\frac{D}{0}$ milder swallowing difficulties, which usually receige little attention from medical staff, are nevertheles associated with poorer functional outcome, even afte adjusting for differences in overall stroke severity. $\stackrel{+}{+}$

It should be noted, however, that correlation analysis only gives an indication of the linearity of 0 associations between variables, before and after such adjustments are made. Since multivariate linear models depend on mathematical assumptions which may not always be valid, the method should not be $\mathbb{2}$ used to estimate the clinical significance of these $\overrightarrow{\vec{O}}$ associations. Nevertheless, the fact that the relation- 3 ship between dysphagia and poor outcome appears independent of other measures of stroke severity? points to a causal link which deserves further study.

Current evidence suggests that the time available after the onset of stroke symptoms for effective: intervention to reverse or limit ischaemic brain damage may be very short. The possibility that $\delta$ dysphagia leads to potentially reversible morbidity $₹$ offers an opportunity for beneficial intervention on a 0 timescale of days rather than minutes or hours, and thus needs further investigation.

The author was supported by a research grant from $\mathcal{N}$ ICI Pharmaceuticals PLC. I am most grateful to DrN S B Ebrahim for help with patient recruitment and to 
Professor J R A Mitchell for much help and advice. I also thank all Nottingham physicians for allowing me to study patients under their care.

\section{References}

1 Willoughby EW, Anderson NE. Lower cranial nerve motor function in unilateral vascular lesions of the cerebral hemisphere. Br Med J 1984;289:791-4.

2 Barer D. Lower cranial nerve motor function in unilateral vascular lesions of the cerebral hemisphere. $\mathrm{Br} \mathrm{Med} \mathrm{J}$ 1984;289:1622 (letter).

3 Veis SL, Logemann JA. Swallowing disorders in persons with cerebrovascular accident. Arch Phys Med Rehabil 1985;66:372-5.

4 Horner J, Massey EW. Silent aspiration following stroke. Neurology 1988;38:317-9.

5 Gordon C, Langton Hewer R, Wade DT. Dysphagia in acute stroke. Br Med J 1987;295:411-4.

6 Barer D. Dysphagia in acute stroke. Br Med J 1987; 295:1137-8 (letter).

7 Barer D, Cruickshank JM, Ebrahim SB, Mitchell JRA. Low dose beta blockade in acute stroke ("BEST" trial): an evaluation. $\mathrm{Br} \mathrm{Med} J \mathrm{1988;296:737-41}$

8 Barer D, Ebrahim SB, Mitchell JRA. The pragmatic approach to stroke trial design. Neuroepidemiology 1988;7:1-12.

9 Ebrahim SB, Nouri F, Barer D. Measuring disability after a stroke. J Epidemiol Community Health 1985; 39:86-9.

10 Barer D, Mitchell JRA. Predicting the outcome of acute stroke: do multivariate models help? Q J Med 1989 (In press).

11 Ozaita G, Calandre L, Peinado E, Rodriguez A, Bermejo F. Haematocrit and clinical outcome in acute cerebral infarction. Stroke 1987;18:1166-8.
12 Scandinavian Stroke Study Group. Multicentre trial of haemodilution in acute stroke: results of subgroup analysis. Stroke 1988;19:464-71.

\section{Appendix}

Rating scales for neurological assessments

1. Conscious level: $\quad 1=$ alert; $2=$ drowsy, responding to speech; 3 = responding to pain only

2. Conjugate gaze $1=$ normal; 2 = will not look paresis: $\quad$ towards affected side; $3=$ eyes deviated at rest away from affected side

3. Sensation on affected $1=$ normal; 2 = inattention side: $\quad$ (sensory extinction); $3=$ no appreciation of touch

4. Grade of speech:* $1=$ normal communication; 2 = some understandable sentences; $3=$ reliably indicates "yes" or "no"; $4=$ nil

5. Response to command:

(a) "raise your good hand" (assisted by gesture)

(b) "touch your left ear with your right hand" (or vice versa)

$1=$ does (a) and (b); $2=$ does (a) only; $3=$ neither

6. Power in affected $\quad 1=$ normal; $2=$ weak but moves arm or leg:

7. Facial movements:

8. Visual fields: against resistance; $3=$ moves against gravity only; $4=$ unable to lift limb; $5=$ no movement

$1=$ normal 2 = impaired $1=$ normal to confrontation; $2=$ inattention (sensory extinction) on affected side; $3=$ hemianopia

9. Bladder control: $\quad 1=$ fully continent; 2 =occasional incontinence; $3=$ wet at least twice a day; $4=$ catheter

* Speech disorder classified into dysphasia, dysarthria, dysphonia 